\title{
長野県の透析の現況
}

$\begin{array}{llllllll}\text { 中 島 貞 男 } & \text { 西尾 } & \text { 康 英 } & \text { 床尾 万寿雄 } & \text { 山口 } & \text { 博 } \\ \text { 荻 原 裕 房 } & \text { 熊 谷 悦子 } & \text { 樋口 } & \text { 誠 } & \text { 北 } & \text { 原 } & \text { 修 } \\ \text { 立花 直 樹 } & \text { 洞 } & \text { 和 彦 } & \text { 小口 } & \text { 寿夫 } & & & \end{array}$

key words：長野県, 透析療法, 現況, 高齢化社会

〈要旨〉

長野県は，農村型社会で日本有数な高齢化社会である。しかしながら，老人医療費は全国最低基準，平均寿命は 全国トップクラスと極めて特筆すべき医療事情を有している. 今般, 我々は 1997 年末の「わが国の慢性透析療法の 現況」から長野県の現況を抽出するとともに, 各施設にアンケート調査を行い, 透析患者の疫学的調査を行った。

長野県の透析患者総数は, 総人口と同じく全国の $1.7 \%$ を占め, 人口 100 万人対透析患者数は 1,323 人でほぼ全国 平均であったが, 入院透析の比率は全国の半分以下であった. 長野県の透析導入患者の平均年齢は, 全国より 1.2 歳 高く, 年齢別では 60〜69 歳が多かった。 導入原疾患では, 全国より慢性腎炎が多く, 糖尿病性腎症が少ない傾向を 示した. 透析患者の死因では, 長野県は心不全が少なく, 脳血管障害が多かった. 1992 年以降の生存率は, 全国平 均以上を示した. 透析従事職員は, 看護婦数は充足していたが, 医師と臨床工学技士数の低下が顕著であった. 長 野県を 4 地域に分けてのアンケート調査では, 人口密度の低い南信地区で患者送迎率が高く, 通院時間, 距離が短 い傾向にあった。一足早い, 長野県における超高齢化社会の到達は, 今後の医療行政に生かされなければならない.

\section{An epidemiological study of dialysis treatment as of December 31, 1997 and how to attend a dialysis unit as of March 31, 1998, in Nagano Prefecture}

Sadao Nakajima, Yasuhide Nishio, Masuo Tokoo, Hiroshi Yamaguchi, Hirofusa Ogihara, Etsuko Kumagai, Makoto Higuchi, Osamu Kitahara, Naoki Tachibana, Kazuhiko Hora, Toshio Oguchi Nagano Dialysis Association

Nagano Prefecture (Nagano) is an area typified by farm villages and is an area with one of the most elderly populations in Japan. However, there is an interesting medical phenomenon in Nagano; the medical expenses for elderly men are very low and there is a high average life span. We extracted the data of the present status of Nagano from "an overview of dialysis treatment in Japan (as of Dec. 31, 1997)." A questionnaire investigation for epidemiology of dialysis patients in each dialysis unit was performed.

The dialysis patients in Nagano occupied $1.7 \%$ of the whole country in the same way as the total population, and the dialyzed population rate per million people was almost equal to the national average. However, the rate of hospitalized dialysis patients was low. The average age of the patients who started dialysis in Nagano was higher than that of the whole country by 1.2 years. In Nagano, the patients who started dialysis due to chronic glomerulonephritis were much more numerous than those of the whole country, and those who started dialysis due to diabetic nephropathy were fewer. In the cause of death of dialyzed patients, the rate of heart failure was low, but that of cerebrovascular disease was high. Regarding dialysis staff members, the number of nurses was sufficient, but there were insufficient numbers of doctors and medical engineers.

The questionnaire investigation divided Nagano into 4 areas. The south part of Nagano, where the population density is lowest, had a high patient pick-up rate, and short time and distance from each dialysis unit. The presence of the super-aging society in Nagano will require some special consideration for future medical

中島 貞男 飯田市立病院内科 ₹ 395-8502 飯田市八幡町 438（0265-21-1255）

Sadao Nakajima Fax 0265-21-1266 
administration.

\section{はじめに}

1966 年以来, わが国の透析患者の統計がとられ, 1974 年以降, 日本透析医学会統計調査委員会より「わ が国の慢性透析療法の現況」が発表され，現在のわが 国の透析患者総数，導入患者数はもちろん，導入原疾 患の変遷や, 最近では生命予後解析も加わっている ${ }^{1)}$.

しかしながら，各都道府県単位でまとめた試みはま だない. 昭和 43(1969) 年秋に発足した長野県透析研究 会は, 平成 10 (1998) 年 10 月に第 46 回大会を開催し, その際 30 周年記念行事を挙行し, 長野県の透析の現況 についてまとめてみた。長野県の透析患者の疫学的背 景を全国の透析患者のそれと比較して明らかにするた めに, 委員会発表の現況報告から長野県のデータを抽 出するとともに, 我々独自にアンケート調査を行って, 患者の通院等について検討したので, ここに報告する.

\section{I . 対象·方法}

\section{1.日本透析医学会統計調查委員会の統計調査資料に 基づいた検討}

1997 年末現在の日本透析医学会統計調査委員会の 調査対象となった透析施設は, 3,026 施設である. 1997 年末現在, 長野県の透析施設は 53 施設であり,この施 設における疫学的デー夕を全国集計より抽出した.

\section{2. 長野県透析研究会による調査資料に基づく検討}

1998 年 3 月末日現在の全透析患者の通院時間, 通院 距離, 通院手段（鉄道，バス，徒歩，自家用車（自分
で運転），送り迎え），CAPD 患者数，長期（社会的） 入院患者数,さらに今後の透析患者受け入れ可能数を, 各施設に一定の書式を送付し, 一定期間後回収して検 討した。

なお， 3 月末には透析施設数は， 1 施設増えて 54 施 設となっていた

\section{II。結果}

\section{1. 日本透析医学会統計調査委員会の統計調査資料に 基づいた検討}

表 1 に透析患者総数などの長野県と全国の比較の表 を示した，長野県の透析患者総数，コンソール数，導 入者, 死亡者, 同時透析能力は, すべて全国の $1.7 \%$ を 占めた. 施設数は $1.75 \%$, 最大収容能力は $1.5 \%$ であっ た. 長野県の総人口は, 1998 年 10 月 1 日現在で $2,214,721$ 人 $^{2)}$ であり, 98 年 10 月における全国の人口 $12,648,600$ 人 $^{3)}$ の $1.75 \%$ を占めており, 前述の各因子 数はほぼ同じ割合が反映されていた。また，長野県の 人口 100 万人対透析患者数は 1,323 人であり，全国的 には 1,149 人から 1,987 人までの範囲を占めた中で, 全国平均（1,395人）よりやや低めであった.

表 2 には，長野県と全国の透析時間や方法の比較を 示した. CAPDや家庭透析を含む全透析患者を分母と して，昼間透析患者を分子として昼間透析率を算定す ると，長野県も全国もおよそ $75 \%$ 程度であった（長野 県 $75.7 \%$ ，全国 $74.6 \%$ ）。また，長野県の昼間透析患 者数は全国の昼間透析患者数に比して $1.7 \% て ゙ あ り ，$ 夜間透析患者数および CAPD 患者数についても,それ

表 11997 年および 96 年末における長野県と全国の比較

\begin{tabular}{l|rrrrrrr}
\hline & 施設数 & コンソール & 患者総数 & 導入者 & 死亡者 & 同時透析能力 & 最大収容能力 \\
\hline 97 年県 & 53 & 1,129 & 2,927 & 477 & 268 & 1,116 & 3,227 \\
96 年県 & 51 & 1,076 & 2,762 & 403 & 240 & 1,067 & 3,221 \\
97 年国 & 3,026 & 66,880 & 175,988 & 28,870 & 16,102 & 66,056 & 212,862 \\
96 年国 & 2,961 & 63,742 & 167,192 & 28,409 & 15,174 & 62,942 & 198,105 \\
\hline
\end{tabular}

表 2 透析方式の比較

\begin{tabular}{l|rccrrr}
\hline & \multicolumn{1}{|c|}{ 昼間 } & 夜間 & 家庭透析 & CAPD & IPD & 計 \\
\hline 長野県 & 2,217 & 564 & 1 & 145 & 0 & 2,927 \\
$\quad$ うち入院 & 214 & & & 10 & & 224 \\
96 年県 & 2,097 & 531 & 0 & 120 & 13 & 2,761 \\
\hline 全国 & 131,321 & 35,368 & 90 & 9,062 & 147 & 175,988 \\
$\quad$ うち入院 & 29,277 & & & 1,012 & 50 & 30,339 \\
96 年全国 & 123,025 & 35,289 & 14 & 8,715 & 149 & 167,192 \\
\hline
\end{tabular}




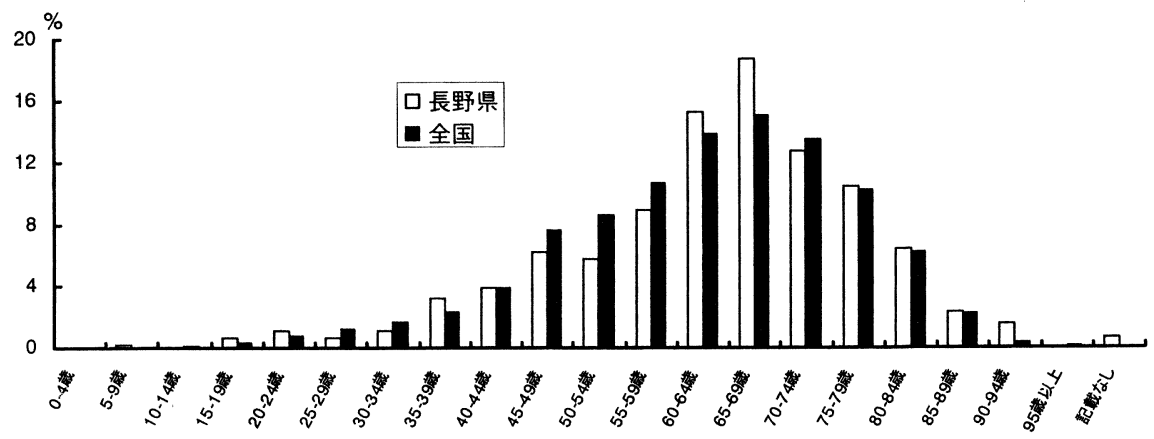

図 197 年導入患者の年齢別比較. 長野県は 468 人, 全国は 29,283 人のデー夕 である. 長野県は 60〜 69 歳が多く, 全国では 45〜59 歳が多い. Y 軸は, 全導入患者に占める\%を示す。

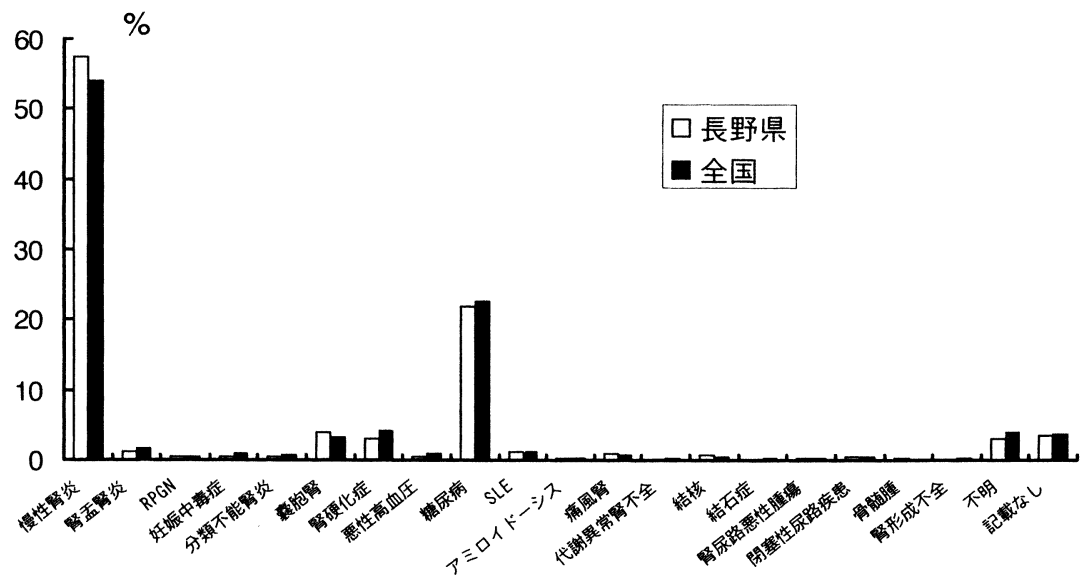

図 2 透析患者の原疾患の比較. 長野県は 2,522 人, 全国は 173,162 人のデー 夕である、Y 軸は, 全原疾患に占める\%を示す。

ぞれ $1.6 \%$ 割合であった。しかしながら, 入院血液透 析者数については長野県は 214 人であり, 全国の 29,277 人に比べると $0.73 \%$ に相当した. 血液透析の入 院透析者が全血液透析患者数に占める比率は, 長野県 が $7.7 \%$, 全国が $17.6 \%$ ，また，CAPD 患者の入院透 析者が全 CAPD 患者数に占める割合は，それぞれ $6.9 \%$ と $11.2 \%$ で, いずれも長野県が大幅に少なく なっていた。

なお, 長野県の入院患者数 (血液透析患者と CAPD 患者の合計）は統計調査委員会の調査では，224人で あったが，これは 1997 年 12 月末の入院透析患者（長 期短期を問わず）を示すものであり，1998 年 3 月末の 我々独自の調査での入院患者数の 113 人とは，異なる ものである. 我々の調査では, 入院患者は 6 か月以上 入院の長期入院患者数を示し，その内訳は通院不可能 など社会的な入院が多い.

最長透析歴は, 長野県では 27 年 9 か月の男性であ り，全国では 31 年 0 か月の男性であった。導入患者の
平均年齢は，長野県 63.42 歳，全国 62.22 歳であり, 透析患者全体の平均年齢は長野県 61.28 歳, 全国 59.23 歳といずれも長野県の方が高齢であった。ちな みに平均寿命は, 1996 年で男は長野県 78.59 年, 全国 77.01 年, 女は長野県 84.40 年, 全国 83.59 年であっ $た^{4,5)}$.

図 1 には, 97 年導入患者の年齢別比較を示した. 長 野県, 全国とも 65〜69 歳で最頻值であったが, 全国で は 45〜59 歳が多く, 長野県では 60〜 69 歳が多かった.

透析患者の原疾患は, 図 2 に示すごとく, 慢性系球 体腎炎 (以下, 慢性腎炎) が長野県 57.5\%, 全国 54.1\% と第 1 位であり，2 位には糖尿病が長野県 $21.8 \%$, 全 国 $22.7 \%$ と続いた。長野県 3 位は囊胞腎，4位腎硬化 症, 5 位腎孟腎炎とSLE であり, 全国 3 位は腎硬化症, 4 位囊胞腎, 5 位腎孟腎炎であった. 新規透析導入患者 の原疾患では, 慢性腎炎が 1 位で長野県 $37.6 \%$, 全国 $36.6 \%$ であった。 2 位は糖尿病で長野県 $32.2 \%$, 全国 $33.9 \%$ であった（図 3 ）。長野県 3 位は, 腎硬化症 


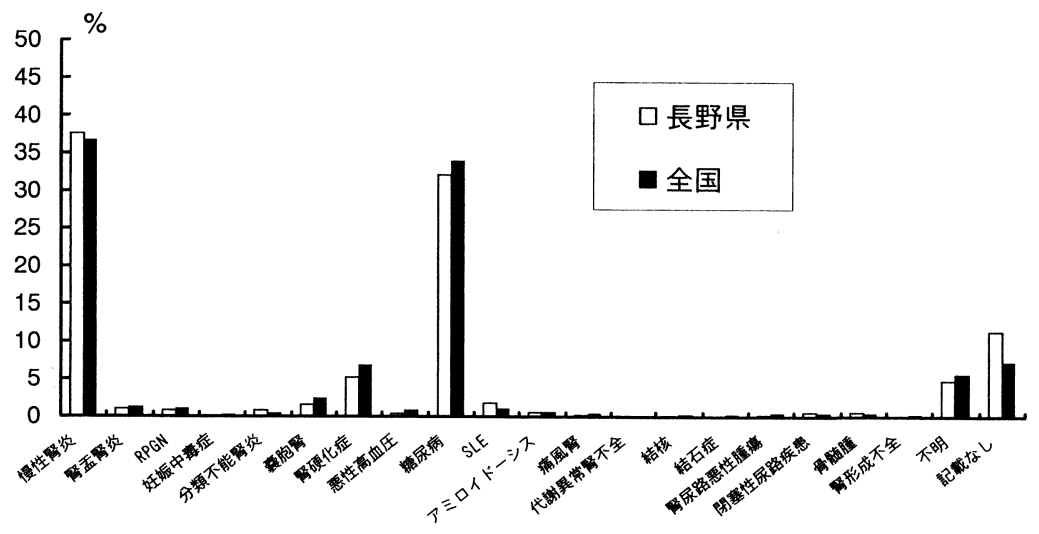

図 3 透析導入原疾患の比較. 長野県 460 人, 全国 29,283 人のデータである. $\mathrm{Y}$ 軸は，全導入疾患に占める\%を示す。

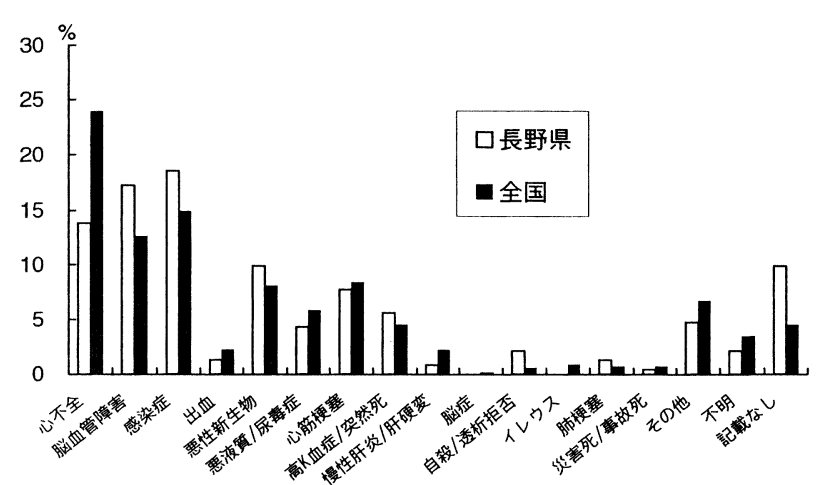

図 4 透析患者の死因の比較，長野県 232 人，全 国 14,962 人のデータである. Y 軸は, 全透 析患者死亡に占める\%を示す。

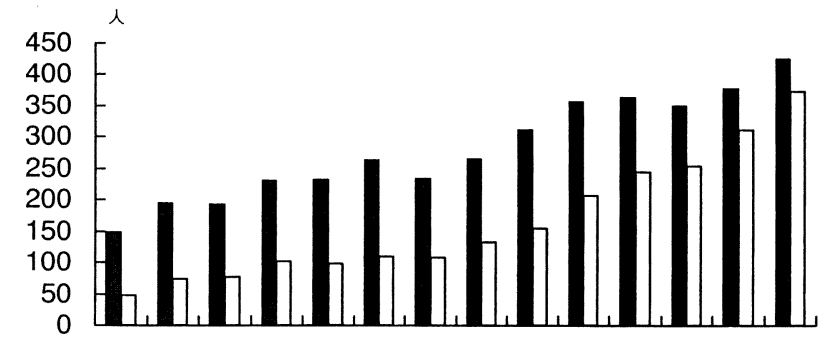

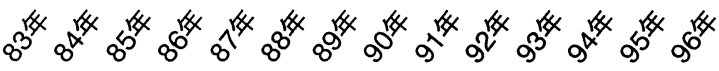

図 5 県導入患者の生存率. 左の棒グラフはその 年の導入者総数, 右の棒グラフは生存者数 を示す. 県の累積導入者は, 3,961 人に達し た。

$5.2 \% ， 4$ 位 SLE，5 位囊胞腎となった．全国では，3 位 腎硬化症 $6.8 \%, 4$ 位囊胞腎，5 位腎跙腎炎と続いた。 長野県には記載なしが $11.3 \%$ と多く，これが正確に評 価されると順位が変わる可能性が考えられた。

図 4 には, 透析患者の死因の比較を示した. 3 大死因 である, 心不全, 感染症, 脳血管障害は長野県も全国 も 1 位から 3 位を占めたが，順位は大きく異なり，長 野県 1 位は感染症で $18.5 \%$, 次いで脳血管障害

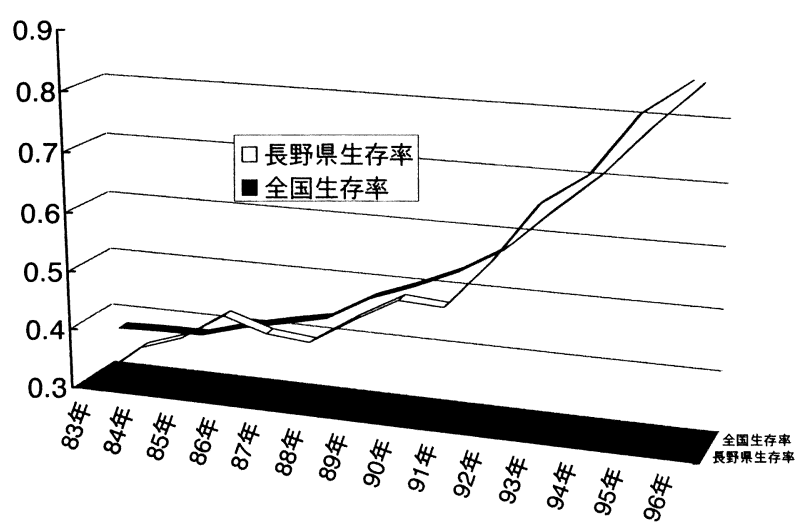

図 6 新規導入患者生存率. 長野県は, $85 \sim 87$ 年 と 93 年以降で全国平均を上回った.

$17.2 \%$ ，そして心不全 $13.8 \%$ であった. 全国では心不 全が圧倒的に多く, $23.9 \%$ ありあ, 続いて感染症 $14.9 \%$ ，脳血管障害 $12.6 \%$ であった，第 4 位は長野県 では悪性新生物, 全国で心筋梗塞となった。

長野県の透析導入患者の生存率を，図 5 に示した。 1983 年導入患者は 150 人であり, 現存しているのは $31.5 \%$ の 47 人である. 1996 年導入者は 427 人で $87.6 \%$ の 374 人が現存している.この結果を全国と比 較したものが図 6 である. $50 \%$ 生存を表す 0.5 に相当 するポイントは, 長野県も全国も 1990 年導入者で長野 県 0.501 , 全国 0.502 であった。長野県は, 1985 年か ら 87 年までと, 1993 年から 96 年までで全国平均を 1.7 から $3.7 \%$ も凌駕した. とくに 1993 年導入者にお いては，全国 4 位と上位に位置した。

図 7 および 8 には，透析専従職員と兼務職員の比率 の比較を示した．比率的には長野県も全国も同様な傾 向ではあった。しかし，専従職員では，長野県におい て医師が全透析従事専従職員中の $7.0 \%$ 占めるのに 対し, 全国では $8.2 \%$ であった. 同様に, 臨床工学技士 は，長野県 $12.5 \%$ に対し，全国 13.8\%であり，長野県 が少ない傾向を示した。また，兼務職員でも，医師は 


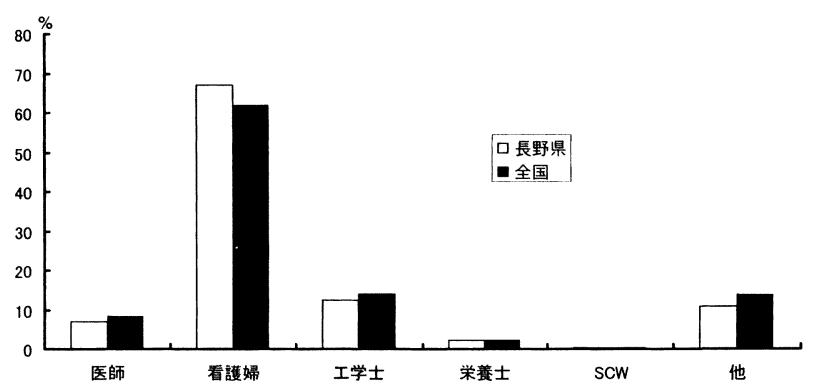

図 7 透析専従職員の比較 (\%)。長野県は, 医師, 臨床工学技士の比率が低く,看護婦は高い Y 軸は，全透析専従職員に対する\%を示 す.

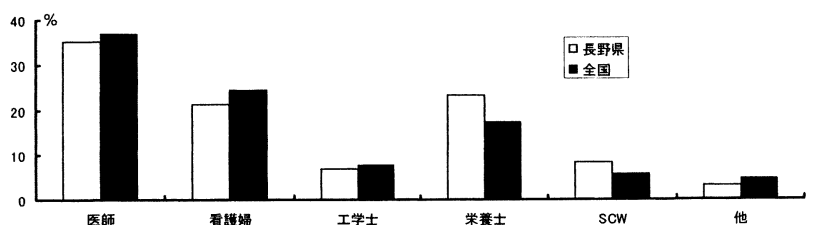

図 8 透析兼務職員の比較 (\%). 長野県は, 医師, 看護婦, 臨床工学技士の比率が低く, 栄養 士, social case worker (SCW) が高い. $\mathrm{Y}$ 軸は，全透析兼務職員に対する\%を示 す.

表 3 患者 10 人当たり透析職員

\begin{tabular}{l|l|cccccc|c}
\hline & & 医師 & 看護婦 & 工学士 & 栄養士 & SCW & 他 & 計 \\
\hline \multirow{2}{*}{ 専従 } & 長野県 & 0.15 & 1.41 & 0.26 & 0.05 & 0.01 & 0.23 & 2.10 \\
& 全国 & 0.18 & 1.37 & 0.31 & 0.05 & 0.01 & 0.30 & 2.21 \\
\hline \multirow{2}{*}{ 兼務 } & 長野県 & 0.45 & 0.27 & 0.09 & 0.30 & 0.11 & 0.06 & 1.27 \\
& 全国 & 0.47 & 0.31 & 0.10 & 0.22 & 0.07 & 0.10 & 1.27 \\
\hline
\end{tabular}

表 4 地区別透析の現況

\begin{tabular}{c|c|c|c|c|c|c|c|c|c}
\hline & $\begin{array}{c}\text { 人口密度 } \\
\left(\text { 人 } / \mathrm{km}^{2}\right)\end{array}$ & $\begin{array}{c}\text { 老年人口 } \\
(\%)\end{array}$ & $\begin{array}{c}\text { 開始時 } \\
\text { 患者数 }\end{array}$ & 患者数 & $\begin{array}{c}\text { 患者数 } \\
(\text { 人/100 万 })\end{array}$ & CAPD & $\begin{array}{c}\text { 入院 } \\
\text { 患者 }\end{array}$ & $\begin{array}{l}\text { 施設 } \\
\text { 数 }\end{array}$ & $\begin{array}{l}\text { 受け入れ } \\
\text { 可能数 }\end{array}$ \\
\hline 北信 & 264 & 19.9 & 52 & 780 & 1,149 & 86 & 21 & 12 & 153 \\
東信 & 170 & 21.4 & 43 & 615 & 1,456 & 19 & 29 & 10 & 248 \\
中信 & 117 & 20.0 & 53 & 692 & 1,306 & 44 & 22 & 13 & 170 \\
南信 & 146 & 21.4 & 115 & 758 & 1,304 & 9 & 41 & 19 & 277 \\
\hline 全県 & 163 & 20.5 & 263 & 2,927 & 1,323 & 158 & 113 & 54 & 848 \\
\hline
\end{tabular}

長野県 $35.2 \%$ に対して全国 $36.9 \%$, 臨床工学技士はそ れぞれ 6.7\%対 $7.8 \%$ と,長野県は全国に比して比率が 少なく，この両業種の絶対数の不足が窥われた。この 傾向は，患者 10 人当たりの透析職員（表 3 ）にても同 様の結果であり, 専従者で医師は長野県 0.15 に対し, 全国 0.18 , 工学士は長野県 0.26 に対し, 全国 0.31 で あった，反面，看護婦は長野県の方に多かった，兼務 者では，長野県では栄養士が多かった，

\section{2. 長野県透析研究会による調査資料に基づく検討}

私どもは，独自調査にて通院状況を調查した。長野 県全体の透析患者 2,927 人中 2,845 人から回答が得ら れ，回収率は $97.2 \%$ あった。，長野県を北信，東信， 中信, 南信の 4 ブロックに分け, 地区ごとの人口密度, 65 歳以上の老年人口, 透析患者数と施設数, CAPD 数, 入院患者数, 受け入れ可能数を表 4 に示した。人口密 度は北信に高く，老年人口は東南信に高值であった。 老年人口の長野県平均は $20.5 \%$ であり, 全国平均の $16.2 \%$ に比して，かなり高齢化が進んでいることが示
唆された．地区ごとの透析患者数は人口 100 万人当た り 1,149 人から 1,456 人であり, 東信に多く, 北信に 少なかった，CAPD は，北高南低の傾向を示した，長 期入院患者は 113 人であり，南信に多かった。

表 5 には，地区別の透析患者の通院状況を示した。 平均通院時間は 19.0 分, 平均通院距離は $8.9 \mathrm{~km}$ であ り, 南信が通院時間, 距離とも他の 3 地区に比べ少な かった，最長は， $60 \mathrm{~km} ， 90$ 分かけて通う患者であっ た，通院手段で，徒歩や自分で公共交通手段を用いた り，あるいは車を運転してくる率を自力通院率とする と, 平均自力通院率は $59.6 \%$ であった。 また, 家人や 知人，業者などによる送迎は，すべて車を利用するも のであったが, $26.5 \%$ を占め, 南信地区で大であった.

\section{III. 考 案}

長野県の透析の現況を知るために，まず，統計調査 委員会による全国集計データから長野県分を抽出し 
表 5 地区別透析患者通院状況

\begin{tabular}{l|c|c|c|c|c}
\hline & $\begin{array}{c}\text { 通院時間 } \\
(\text { 分 })\end{array}$ & $\begin{array}{c}\text { 通院距離 } \\
(\mathrm{km})\end{array}$ & $\begin{array}{c}\text { 自力通院率 } \\
(\%)\end{array}$ & $\begin{array}{c}\text { 送迎率 } \\
(\%)\end{array}$ & $\begin{array}{c}\text { 最長 } \\
(\mathrm{km})\end{array}$ \\
\hline 北信 & $19.1 \pm 13.6$ & $8.6 \pm 7.7$ & 60.5 & 21.5 & 50 \\
東信 & $19.4 \pm 13.4$ & $9.8 \pm 8.5$ & 57.9 & 30.7 & 50 \\
中信 & $20.8 \pm 17.4$ & $10.5 \pm 10.9$ & 61.7 & 18.5 & 60 \\
南信 & $16.9 \pm 13.0$ & $6.9 \pm 7.0$ & 58.5 & 34.7 & 50 \\
\hline 県全体 & $19.0 \pm 14.5$ & $8.9 \pm 8.7$ & 59.6 & 26.5 & \multicolumn{3}{|c}{ (mean $\pm \mathrm{SD})$} \\
\hline
\end{tabular}

た。

長野県の透析人口は 2,927 人で全国の $1.7 \%$ 占 め, これは全国総人口に占める長野県の割合と同程度 であった.このことは透析導入者に関しても同等で, 長野県の独自性はなかった。しかしながら，入院透析 者の全血液透析患者に対する比率は，全国の $17.6 \%$ に 対して長野県は $7.7 \%$ と低かった。CAPD患者におい ても入院者は全国の $11.2 \%$ に対し，長野県は $6.9 \%$ と 低值を示した. 長野県は, 1997 年調査において平均世 帯人員は全国の 2.79 人 $^{6)}$ に対し， 3.0 人 $^{2)}$ と多く，大家 族制が維持されており，核家族化が進んでいないこと が原因の一つと思われた。 ちなみに長野県の世帯数 3.0 人は, 全国の 10 年前のデータに值する.

長野県の平均寿命は全国のトップレベル ${ }^{5,7)}$ (男 1 位· 78.08 年, 女 4 位· 83.89 年；1995 年)にあり, そ の反面， 1 人当たりの老人医療費は 1995 年度で全国 75.2 万円 ${ }^{8)}$ に対し，長野県 54.7 万円 ${ }^{9)}$ と全国で最も低 いものとなっている，県民の保険に対する意識が高い ことや, 一人暮らしの老人が少ないこと, 保健啓蒙活 動が活発なこと, などが理由としてあげられている10). こうしたことが，入院透析率の減少に寄与したと考え られた。しかし，透析患者の平均年齢，導入患者の平 均年齢は，共に全国平均を上回っており，長野県の患 者の高齢化が進んでいることが如実に示された.

こうしたことは，透析患者全体および導入患者の原 疾患統計にも反映される。すなわち現在，全国集計で は透析原疾患は慢性腎炎が減り，糖尿病性腎症が増加 している。長野県では全国に比してまだまだ慢性腎炎 由来が多く，糖尿病性腎症由来は少ない，透析患者全 体では，長野県では腎炎由来は全国に対し $3.4 \%$ 多く, 糖尿病由来は $0.9 \%$ 少なかった. 導入患者では, 長野県 では腎炎は全国に比して $1.0 \%$ 多く,糖尿病では $1.7 \%$ 少なかった。

透析患者の死因では，長野県と全国に大きな違いが 認められた. 3 大死因こそ同じであったが, 長野県では 脳血管障害, 感染症が多く, 全国では心不全が圧倒的 に多かった. 1995 年における死因別年齢調整死亡率 ${ }^{11}$
では長野県における死因別死亡率は, 脳血管障害は男 で全国 9 位, 女で 14 位と高かったが, 心不全は男で全 国 38 位，女で 42 位であり，長野県における特徵が透 析患者においても反映されていた。

長野県における導入患者の生存率は, 1993 年以降, 全国平均以上となっている. 平均寿命も 1990 年以降 トップレベルの男 1 位, 女 4 位となっており，こうし たことが透析患者においても反映されたと考えられ た.

しかし，透析職員数は全国に比して少なく，医師お よび臨床工学技士の数不足は明らかであった。他方, 専従看護婦が多いことが，あるいは導入患者の生存率 向上に寄与したかもしれない.

長野県の特徴は農村地帯が多いことであり, 高齢化, 大家族制はその一つの特徵といっても過言ではない. 透析患者の高齢化, 原疾患の長野県と全国の比較で糖 尿病性腎症が少なく，慢性腎炎が多いこと，死因に脳 血管障害が $4.6 \%$ 多く， 心不全が $10.1 \%$ 少ないこと， 透析職員に看護婦は多く，医師や臨床工学技士が少な いことなどは,こうした農村社会の反映と考えられた。 さらに，入院透析率の低いことも大家族制のなせる結 果と考えられた。

通院状況は, 長野県を 4 ブロックに分け調査したが, 地域的な差が浮上した。長野県では北信地方に圧倒的 に人口密度が高く, 従い市部も多い. しかしながら, 透析患者の通院時間や距離に関しては南信の数字が最 も少なかった，南信の面積は，中信に次いで広いが, 透析患者は人口の多い市部に集中していると思われ た. 自力通院率や送迎率を求めてみると, 南信では送 迎率が高く, このことも通院時間, 距離短縮に寄与し ていると考えられた．公共交通手段の充実も自力通院 率を上げるに役立つと考えられるが，北信，中信で高 かったものの，他地区と比べ，さほどの差はみられな かった。

老年人口は，全国 16.2\%に比して長野県 20.5\%で あった，長野県と全国の比較において透析患者全体の 平均年歯令で 2.05 歳, 導入患者で 1.2 歳, 長野県の方が 
高齢である一つの原因と考えられる. 65 歳以上の老年 人口を $15 \sim 64$ 歳の生産年齢人口で除した百分率が老 年人口指数であるが，平成 10 年の $23.6 \%$ が，平成 32 年には $46.0 \%$ にもることが予測されている. 現在, 生産人口 5 人に 1 人の老年者をみていることが, 2 人 に 1 人の状況になるわけである ${ }^{12)}$.こうした, 加速的な 高齢化は欧米諸国に比しても急激であり ${ }^{13)}$, 多くの問 題をかかえることとなる。興味深いことに長野県の老 年人口は, 2020 年には, 全国と同じ $26.9 \%$ まで昇し, この時点で全国と同一数字となるが，これ以後は逆に 老年人口の伸びは止まり，2025年には $27.0 \%$ とな る ${ }^{14)}$.しかしいずれにせよ, 厳しい高齢化社会の到来は 事実であり, 今後の対応が苦慮されるものと思われる. 長野県は, 入院透析の比率が低く，その割には透析 患者の高歯化が進んでいる. 透析専従職員の看護婦は, 他職種が全国に比べ少ない中で多い傾向がある.また, 長野県は男 1 位, 女 4 位の全国屈指の長寿県であると 同時に, 都市部が少なく, 全国に比べ 10 年は核家族化 が遅れている．以上のことが，入院透析の比率を低く するとともに，透析患者の高歯化にも寄与したと思わ れた. 1 人当たりの老人医療費は全国最低であり,こう したことが急速に進行する高齢化社会への一つの鍵と して有用である可能性が示唆された.

本論文の一部は, 第 44 回日本透析医学会総会で発表し た.
文献

1）日本透析医学会統計調査委員会：わが国の慢性透析療 法の現況（1997 年 12 月 31 日現在）。透析会誌 $32 ： 1-$ 17, 1999

2）長野県総務部情報統計課：ながの県勢要覧 平成 10 年版, pp 14, 長野県統計協会, 長野, 1999

3）厚生省：平成 11 年度版厚生白書 社会保障と国民生 活，pp 338，ぎょうせい，東京，1999

4）厚生省：平成 11 年度版厚生白書 社会保障と国民生 活, pp 340, ぎょうせい，東京，1999

5）長野県総務部情報統計課：ながの県勢要覧 平成 10 年版, pp 22, 長野県統計協会, 長野, 1999

6）厚生省：平成 11 年度版厚生白書 社会保障と国民生 活, pp 342, ぎょうせい, 東京, 1999

7）厚生統計協会：国民衛生の動向．厚生の指標 45，444446, 1998

8）厚生統計協会 : 国民衛生の動向．厚生の指標 45，235238, 1998

9）全国医療データマップ’98-’99, pp 40-42, ミクス, 東京, 1998

10）鎌田 實：長野県が日本で老人医療費が安い理由.や さしい医学事典 10 巻, 長野県国保地域医療推進協議 会, 長野県国民健康保険団体連合会, 長野, pp 166-179, 1999

11）全国医療データマップ'98-’99, pp 19-21, ミクス, 東京, 1998

12）厚生省：平成 11 年度版厚生白書 社会保障と国民生 活，pp 166-167，ぎょうせい，東京，1999

13）厚生省：平成 11 年度版厚生白書 社会保障と国民生 活, pp 21-22，ぎょうせい，東京， 1999

14）長野県企画局企画課：地球時代に輝く信州をめざして 一長野県中期総合計画一。pp 17，1996 